University of South Carolina

Scholar Commons

$5-1-2009$

\title{
Parallel-Connected Solar PV System to Address Partial and Rapidly Fluctuating Shadow Conditions
}

\author{
Lijun Gao \\ Boeing, Lijun.gao@boeing.com \\ Roger A. Dougal \\ University of South Carolina - Columbia, dougal@engr.sc.edu \\ Shengyi Liu \\ Boeing, shengyi.liu@boeing.com \\ Albena P. Iotova \\ University of South Carolina - Columbia, lotovaa@cec.sc.edu
}

Follow this and additional works at: https://scholarcommons.sc.edu/elct_facpub

Part of the Electrical and Computer Engineering Commons

\footnotetext{
Publication Info

Published in IEEE Transactions on Industrial Electronics, Volume 56, 2009, pages 1548-1556.

http://ieeexplore.ieee.org/xpl/Recentlssue.jsp?punumber=41

(C) 2009 by IEEE
}

This Article is brought to you by the Electrical Engineering, Department of at Scholar Commons. It has been accepted for inclusion in Faculty Publications by an authorized administrator of Scholar Commons. For more information, please contact digres@mailbox.sc.edu. 


\title{
Parallel-Connected Solar PV System to Address Partial and Rapidly Fluctuating Shadow Conditions
}

\author{
Lijun Gao, Senior Member, IEEE, Roger A. Dougal, Senior Member, IEEE, \\ Shengyi Liu, Senior Member, IEEE, and Albena P. Iotova
}

\begin{abstract}
Solar photovoltaic (PV) arrays in portable applications are often subject to partial shading and rapid fluctuations of shading. In the usual series-connected wiring scheme, the residual energy generated by partially shaded cells either cannot be collected (if diode bypassed) or, worse, impedes collection of power from the remaining fully illuminated cells (if not bypassed). Rapid fluctuation of the shading pattern makes maximum power point (MPP) tracking difficult; generally, there will exist multiple local MPPs, and their values will change as rapidly as does the illumination. In this paper, a portable solar PV system that effectively eliminates both of the aforementioned problems is described and proven. This system is capable of simultaneously maximizing the power generated by every PV cell in the PV panel. The proposed configuration consists of an array of parallel-connected PV cells, a low-input-voltage step-up power converter, and a simple wide bandwidth MPP tracker. Parallel-configured PV systems are compared to traditional series-configured PV systems through both hardware experiments and computer simulations in this paper. Study results demonstrate that, under complex irradiance conditions, the power generated by the new configuration is approximately twice that of the traditional configuration. The solar PV system can be widely used in many consumer applications, such as PV vests for cell phones and music players.
\end{abstract}

Index Terms-Complex illumination, maximum power point tracking (MPPT), partial shading, photovoltaic (PV) solar cell, power converter, solar array.

\section{INTRODUCTION}

$\mathbf{I}$ $\mathrm{N}$ PHOTOVOLTAIC (PV) arrays, cells are conventionally connected in series to obtain the desired voltage. In higher voltage applications, bypass diodes may be placed across groups of cells to prevent mismatched or shaded cells [1] from inhibiting production of power by the rest of the array. $\mathrm{PV}$ arrays in portable/mobile applications are often subject to partial shading and rapidly changing shadow conditions. For example, a body-worn PV jacket would be subject to variations of illumination because of continuous movements, both temporally and spatially, due to shading from trees, vehicles, and buildings, as well as due to changes of orientation of the array relative to the sun. The complex operation conditions for

Manuscript received February 19, 2008; revised November 11, 2008. First published January 6, 2009; current version published April 29, 2009.

L. Gao and S. Liu are with the Boeing Company, Seattle, WA 98108 USA (e-mail: Lijun.gao@boeing.com; shengyi.liu@boeing.com).

R. A. Dougal and A. P. Iotova are with the University of South Carolina, Columbia, SC 29208 USA (e-mail: Dougal@cec.sc.edu; Iotovaa@cec.sc.edu).

Color versions of one or more of the figures in this paper are available online at http://ieeexplore.iee.org.

Digital Object Identifier 10.1109/TIE.2008.2011296 portable PV applications are much different from stationary PV applications where typically no obstructions exist and changing of illumination conditions is slow. As a consequence, two problems are generally encountered when using conventional configurations under such complex illumination conditions.

First, although partially shaded cells can still generate a certain amount of energy, that energy cannot be collected in systems of the traditional configuration. If bypass diodes are not used, any shaded cell inhibits power production from the entire series-connected string of cells. If bypass diodes are used, then the fraction of energy that could be generated by the partially shaded cells is still lost even if it does not impede collection of energy from the rest of the cells. Furthermore, in low-voltage arrays, the diode bias voltage may represent a significant fraction of the total PV source operating voltage. These issues are often not significant in high-voltage stationary systems that do not have obstructions, but they are quite significant in low-voltage systems for portable applications where partial shading occurs frequently and quite a fraction of the cells may be partially shaded at any one time. Second, rapidly changing shadow conditions increase the difficulty of maximum power point tracking (MPPT). It is very hard to identify the global maximum power point (MPP) (for diodebypassed systems) because multiple local MPPs exist, and their locations fluctuate rapidly corresponding to the changing shading conditions. Even if at some instant one could know where the global maximum is, it would probably change before it was possible to shift the MPP tracker to that operating point. In other words, very fast tracking speeds and good control stability are particularly required for a MPP tracker to work in this situation.

Addressing these problems, this paper describes and validates a highly parallel-configured PV system that operates effectively in rapidly varying shaded conditions, which is an expansion of the work presented in [2] and [3]. Series connections of cells, if necessary, are limited only to the minimum necessary to present an adequate input voltage $(\sim 1 \mathrm{~V})$ to the step-up converter connected at the output of the PV array, and by considerations of ohmic losses in the bus work. For $\mathrm{Si}$ cells, we are typically considering just two or three cells, but for multijunction PV cells that produce higher voltages, we could use single cells. It is noted that in [4]-[7], PV modules rather than PV cells are connected in parallel and shown to demonstrate better performance in shaded conditions. Each PV module is treated as one unit that tracks its own MPP. Therefore, when a module is shaded, the degradation of performance 


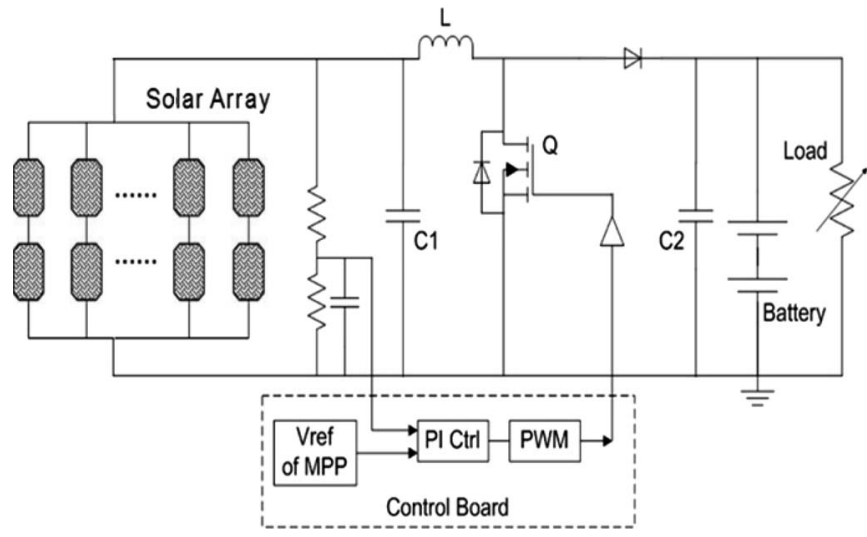

Fig. 1. Circuit diagram of proposed maximally parallel PV system.

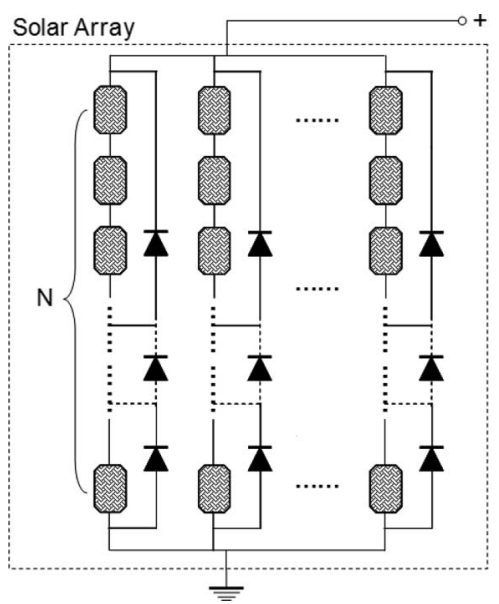

Fig. 2. PV array using conventional configuration.

will not propagate to other modules. The work we report here extends the concept to the microscale appropriate for portable applications at low power and low voltages. The proposed PV system adopts the parallel configuration at the individual cell level, so that every cell in the PV panel can achieve its MPP under nonideal conditions. In contrast to the electric utility scale applications where one needs as many power converters as PV modules, in the low-power case, only a single lowcost converter is required. This paper shows specifically the performance gain of this arrangement and the efficacy in realworld conditions, and it validates the real-world experiments with simulation data.

\section{SySTEM CONFIGURATION}

The developed PV power system, as shown in Fig. 1, has three main characteristics. 1) In contrast to conventional configurations characterized as many cells in series, with or without bypass diodes (shown in Fig. 2), the PV array in the system described here adopts a highly parallel configuration. 2) The MPPT is implemented through controlling the PV array operating voltage to follow a prescribed voltage reference corresponding to the single-cell MPP. 3) A step-up power converter manages the cell loading and boosts the voltage to the system requirements. Considering that in most portable applications there will already be a power converter for battery charge management, there is thus no extra hardware cost to use this configuration.

\section{A. Parallel Configuration}

The PV array is constructed with a highly parallel, rather than serial, wiring configuration. The highly parallel configuration has three important characteristics that are inherited from a single PV cell. 1) The voltage of the MPP is largely independent of illumination, or in other words, even at different irradiance levels, the MPPs of cells connected in parallel occur at nearly a common voltage. 2) Slight deviation from MPP voltage only weakly affects produced power. 3) Voltage of the MPPs is only weakly sensitive to temperature over the usual range (e.g., 20-K difference). As a consequence, the parallel-configured PV array is capable of making every cell in the panel generate nearly maximum power simultaneously, no matter whether the illumination distribution is uniform. Different cells in the panel may supply different currents corresponding to irradiance levels falling on them instantly; however, all the cells share a common voltage that will be controlled to track the MPP.

\section{B. MPPT}

Many MPPT methods have been reported, such as perturb and observe [8]-[12], incremental conductance [13], [14], neural network based [15], [16], fuzzy logic control [17], [18], etc. These approaches have been effectively used in stand alone and grid-connected PV solar energy systems [19]-[22] and work well under reasonably slow and smoothly changing illumination conditions mainly caused by weather fluctuations. However, it is not easy to directly apply these approaches into portable PV applications due to low tracking speeds or complex implementations. Recently, [23] proposed and validated an MPPT algorithm working in conjunction with a dc-dc converter to track the global peaks for PV systems operating under partially shaded conditions. While this approach is designed and suitable for high-voltage PV modules with multicells in series and has a relevant fast tracking speed (typically a couple of seconds), it is not easy to implement directly in portable PV applications since the energy generated from partially shaded cells cannot be collected, and the tracking speed is not fast enough for portable applications where shading conditions may changes rapidly (e.g., tenth of a second).

On the other hand, the MPP of any individual cell is actually rather simple to locate since it is located very near to a particular (temperature dependent) operating voltage [1]. Based on this well-known fact, the MPPT methodology of controlling PV array operating voltage was already developed a few decades ago for series-connected PV arrays [24]-[26]. It is easy to implement and has fast dynamic response to illumination changes. For series connected cells, although, uniform illumination is a precondition to make this method work well; shaded cells will defeat the technique because they will reduce the target operating voltage. Therefore, for portable applications, this technology cannot be directly applied if the PV panel were connected using conventional series configurations. 
However, for parallel-configured PV arrays, integrating this simple MPPT technology actually excludes this limitation and makes MPPT effective under complex illumination conditions.

\section{Input Voltage of Power Converter}

In principle, it is preferred to connect all cells in parallel. However, the terminal voltage of a single-junction Si PV cell is so low (e.g., $\sim 0.4 \mathrm{~V}$ at MPP); this may increase the difficulty of designing an appropriate power converter. If multijunction PV cells (where the single-cell terminal voltage exceeds 1 or $2 \mathrm{~V}$ ) were used, the increased energy efficiency of the power converter at the higher input voltage would permit operation with single cells in parallel. As a tradeoff, for single-junction PV cell, a small number (two or three) of cells can be first connected in series. If the cells are small in size compared to the structure size of the illumination patterns, then the whole string can generally be assumed under uniform irradiance. If at some time instants, any one cell in a short string is shaded, then this situation is equivalent to shading of the whole string. Therefore, the study results are the same whether one cell is shaded, or the whole short string of two or three cells is shaded. This paper has adopted and verified this approach, as detailed in next section. Two parallel-configured PV panels were built, in which one had series strings of two cells and the other with series strings of three cells. Study results demonstrate a significant increase of power produced by both of these nominally parallelconfigured PV arrays compared to a similarly sized seriesconnected string.

Most of current commercialized PV devices for consumer electronics just use simple series configurations, such as cell phone chargers, battery maintainers for automobiles, recreational vehicles, etc. The main reason of using series configuration is because it is easy to build up the PV panel output voltage and, thus, avoiding voltage regulation and achieving low cost; however, the PV source performance will be degraded particularly under complex illumination conditions. With significant developments of power electronics, power converters/inverters today are highly efficient and low in cost and, thus, are being more and more integrated into PV generators. It is noted that, for high-voltage applications, some recent works [4]-[6], [27], [28] have demonstrated uses of parallel-connected PV modules (rather than cells) with advanced power electronics to achieve better performance than conventional series-connected PV modules. For example, [27] describes the parallel connection of six PV modules with open circuit voltage at $21 \mathrm{~V}$, which is then boosted to $200 \mathrm{~V}$ using a step-up power converter.

It is also noted that converters suitable for use with very low input voltages are becoming increasingly common as they are widely used in single-cell battery-powered consumer electronics. For example, some commercialized converters have allowed the minimum input voltage as low as $0.3 \mathrm{~V}$, allowing connect to one PV cell directly. For most portable electronics, one stage of voltage boosting is generally enough. To further obtain a high voltage (e.g., for electric utility scale applications), a cascade topology of per-panel $\mathrm{dc}-\mathrm{dc}$ converters connected into series can be adopted [29], [30]. However, cascading of $\mathrm{dc}-\mathrm{dc}$ converters will decrease the system effi-
TABLE I

COMPARISON OF TWO PV SYSTEMS

\begin{tabular}{|c|c|c|}
\hline Component & Series Configuration & Parallel Configuration \\
\hline PV panel & $\begin{array}{l}20 \text { cells in series, } \\
4 \text { strings in parallel, } \\
2 \mathrm{~cm} \times 2 \mathrm{~cm} \text { per cell } \\
5 \text { cells per bypass } \\
\text { diode }\end{array}$ & $\begin{array}{l}3 \text { cells in series, } \\
27 \text { strings in parallel, } \\
2 \mathrm{~cm} \times 2 \mathrm{~cm} \text { per cell } \\
\text { no bypass diodes } \\
\text { required }\end{array}$ \\
\hline Ultracapacitor & $\begin{array}{l}\text { Maxwell BCAP } 0350 \text {, } \\
350 F \text { per cell, } 2 \text { cells } \\
\text { in series }\end{array}$ & $\begin{array}{l}\text { Maxwell BCAP0350, } \\
350 \mathrm{~F} \text { per cell, } 2 \text { cells } \\
\text { in series }\end{array}$ \\
\hline Power Converter & $\begin{array}{l}\text { Step-down, Maxim } \\
1653\end{array}$ & Step-up, Maxim 1676 \\
\hline
\end{tabular}

ciency and increase the difficulty of control design. Therefore, tradeoffs exist in choosing between series-configured PV panels with single stage power conversion or parallel-configured PV panels with cascaded power conversion. That is to say, conventional series-configured PV systems are more suitable for grid-connected applications with high-voltage requirements, while the parallel configurations proposed in this paper are more suitable for portable/mobile applications with low voltage requirements.

\section{EXPERIMENTAL RESUlTS}

Two hardware tests were carried out to validate the performance of the described approach. The first test compared the conventional configuration to the parallel configuration under complex illumination conditions; the other test verified the feasibility of wide bandwidth MPPT. For convenience, in the following, the conventional configuration is referred to as the series configuration and any mostly parallel configuration is referred to as the parallel configuration even if it contained two or three series cells in each parallel branch.

\section{A. Performance of Parallel Configuration Versus Series Configuration}

As summarized in Table I, the series configuration yielded an open circuit voltage around $10 \mathrm{~V}$ which was then reduced to $3.3 \mathrm{~V}$ by a buck converter; the parallel configuration yielded an open circuit voltage around $1.5 \mathrm{~V}$ which was then increased to $3.3 \mathrm{~V}$ by a step-up converter. Voltage was converted to $3.3 \mathrm{~V}$ in each case to provide power suitable for consumer electronics using typical two cells of NiMH batteries. The $3.3 \mathrm{~V}$ was conveniently chosen here for the purpose of comparison, but could otherwise have been any voltage between the lowest or highest voltages produced by the parallel and series arrays, respectively. Both of the power converters are commercial products (as shown in Table I) for general dc-dc power managements with typical efficiency around $90 \%$ from their data sheets. In each configuration, two cells of ultracapacitors were connected in series and served as the energy repository. The integrated control algorithms in both of the converters were not designed to track the MPP of the PV arrays because, for the series configuration, based on the analysis in Section I, it is actually very difficult to implement any MPPT under rapidly changing shadow conditions. For the parallel configuration, the MPPT can be implemented and will be detailed in the 


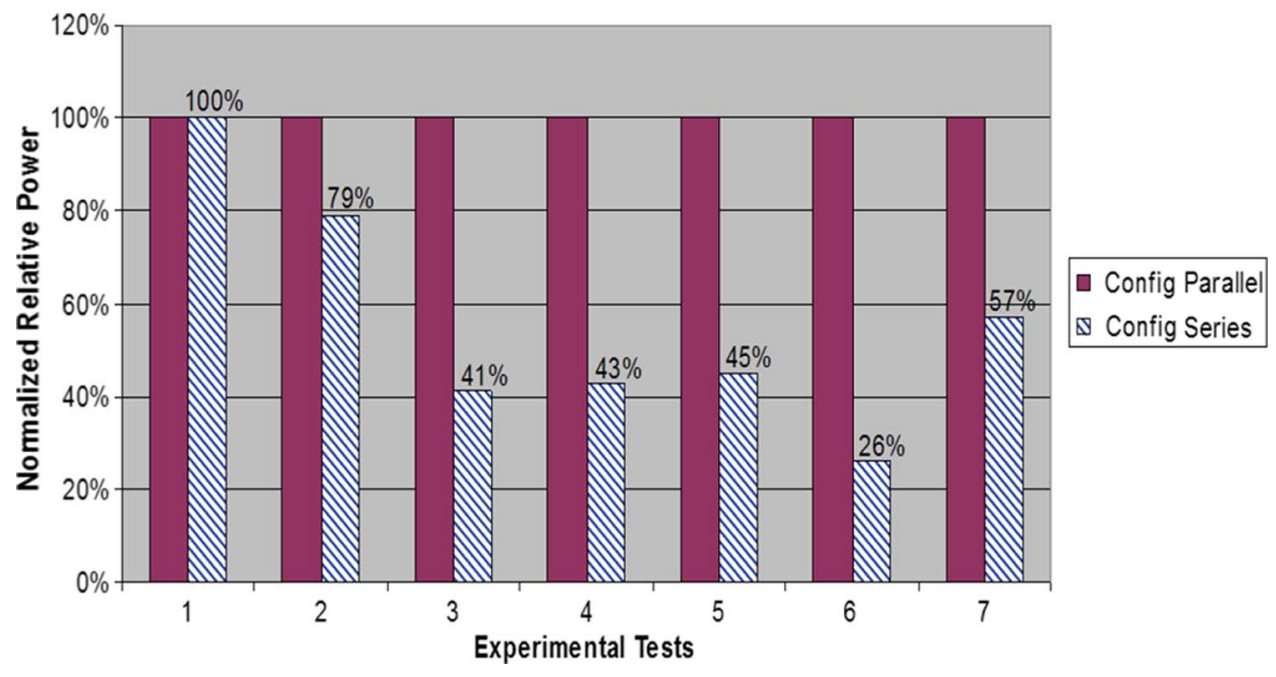

Fig. 3. Comparison of power generation between two PV systems.

TABLE II

DESCRIPTION OF TEST CONDITIONS

\begin{tabular}{|c|c|c|}
\hline & Place & Test Description \\
\hline 1 & $\begin{array}{l}\text { Out-of- } \\
\text { doors }\end{array}$ & $\begin{array}{l}\text { * Area has no shade } \\
\text { * Panels stationary } \\
\text { * Panels positioned horizontally }\end{array}$ \\
\hline 2 & $\begin{array}{l}\text { Out-of- } \\
\text { doors } \\
\text { (Fig. } 4 \text { (a)) }\end{array}$ & $\begin{array}{l}\text { * Area shaded by trees } \\
\text { * Panels constant movement } \\
\text { * Panels positioned horizontally }\end{array}$ \\
\hline 3 & $\begin{array}{l}\text { Out-of- } \\
\text { doors } \\
\text { (Fig. } 4 \text { (b)) }\end{array}$ & $\begin{array}{l}\text { * Area shaded by trees } \\
\text { * Panels constant movement } \\
\text { * Panels positioned about } 70 \text { degrees to the } \\
\text { horizon }\end{array}$ \\
\hline 4 & $\begin{array}{l}\text { Out-of- } \\
\text { doors }\end{array}$ & $\begin{array}{l}\text { * Area shaded by trees } \\
\text { * Panels constant movement } \\
\text { * Panels positioned about } 70 \text { degrees to the } \\
\text { horizon }\end{array}$ \\
\hline 5 & $\begin{array}{l}\text { Out-of- } \\
\text { doors } \\
\text { (Fig. } 4 \text { (c)) }\end{array}$ & $\begin{array}{l}\text { * Area shaded by railing } \\
\text { * Panels stationary } \\
\text { * Panels positioned horizontally }\end{array}$ \\
\hline 6 & $\begin{array}{l}\text { Laboratory } \\
\text { (Fig. } 4 \text { (d)) }\end{array}$ & $\begin{array}{l}* 300 \mathrm{~W} \text { artificial illumination source } \\
* \text { Panels stationary } \\
* \text { Shading: vertical lines, shading area } 53 \%\end{array}$ \\
\hline 7 & Laboratory & $\begin{array}{l}* 300 \mathrm{~W} \text { artificial illumination source } \\
* \text { Panels stationary } \\
* \text { Shading: squares, shading area } 79 \%\end{array}$ \\
\hline
\end{tabular}

second experiment; however, in this first experiment, no MPPT was integrated in order to generate results that were directly comparable to results from the series configuration.

Both of the PV systems were tested in laboratory conditions and in an outdoor environment. At the beginning and the end of each test, the terminal voltages of the ultracapacitors were measured. These voltages were used to calculate the energy charged into the ultracapacitor, and hence, the average power produced by each PV panel. The ultracapacitor packs were precharged to $2.2 \mathrm{~V}$ to simulate two depleted secondary battery cells (e.g., NiMH or NiCd batteries). Seven tests in total were conducted, in which the first five tests were done out of doors, and the last two were done in the laboratory. In each test, the power generated by the parallel configuration was first normalized to $100 \%$, and then it was used as reference to calculate the relative power generated by the series configuration. It can be seen, from Fig. 3, that the parallel configuration showed better

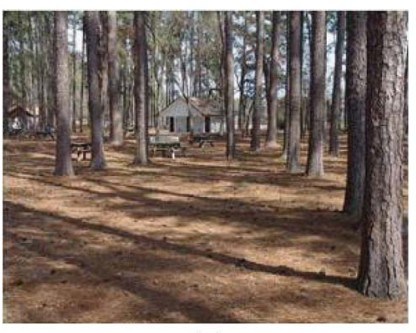

(a)

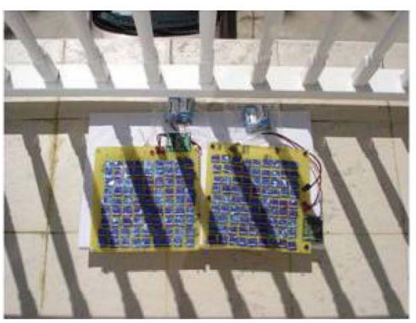

(c)

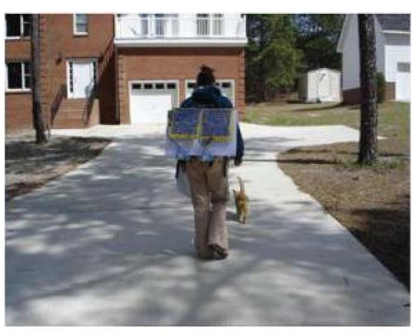

(b)

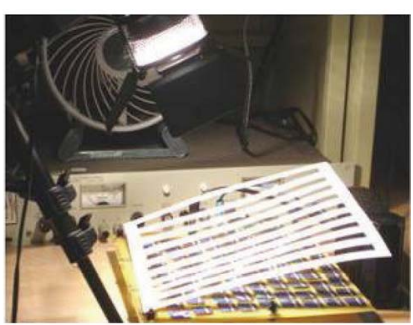

(d)
Fig. 4. Experimental tests under different illumination conditions.

performance and its power generation capability was greater, typically by a factor of two, in partially shaded conditions. Test conditions of seven different experiments are shown in Table II. Pictures in Fig. 4 show the test conditions corresponding to Tests $2,4,5$, and 6 , respectively.

\section{B. Parallel Configuration Integrated With MPPT}

As shown in Fig. 5, the PV system described in Fig. 1 was built and tested in the laboratory. The PV panel contained 80 single-junction Si cells in total arranged with two cells in series then 40 strings in parallel. Two cells of AA size NiCd batteries were connected in series and served as the energy repository. A 300-W high-intensity lamp served as the illumination source and an electronic load was connected to the battery. A pulsed load profile was applied with a regular period a $9 \mathrm{~s}(6 \mathrm{~s}$ of high current demand at $0.4 \mathrm{~A}$ and $3 \mathrm{~s}$ of low current demand at $0.1 \mathrm{~A}$ ). A step-up power converter was interposed between the PV panel and the battery. The MPPT algorithm was defined 


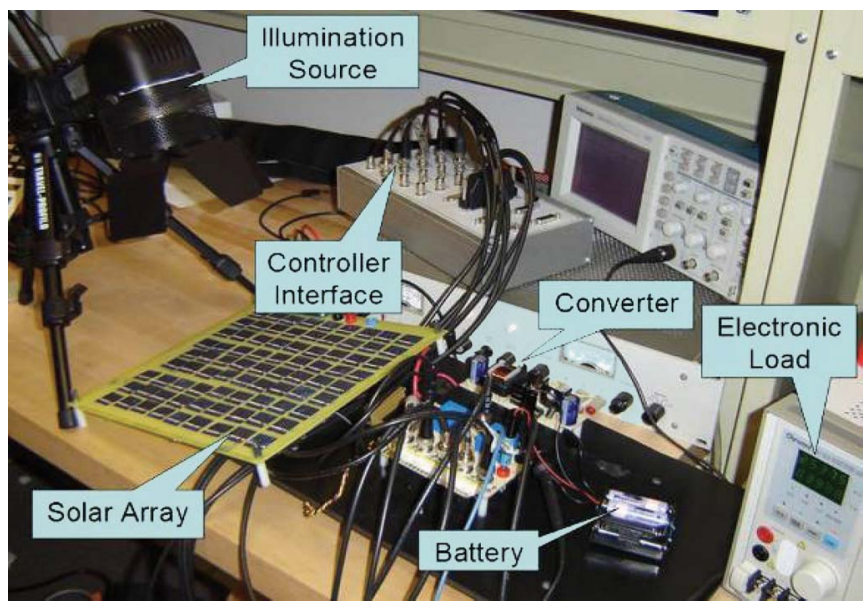

Fig. 5. Experimental test platform.

TABLE III

COMPONENTS USED IN EXPERIMENT PV SYSTEM

\begin{tabular}{l|l}
\hline \multicolumn{1}{c|}{ Component } & \multicolumn{1}{c}{ Description } \\
\hline PV panel & $\begin{array}{l}2 \text { cells in series, 40 strings in parallel. } \\
2 \mathrm{~cm} \times 2 \mathrm{~cm} \text { per c-Si cell }\end{array}$ \\
\hline Battery & $2 \mathrm{AA}$ size Ni-Cd cells in series \\
\hline Illumination source & $300 \mathrm{~W}$ high-intensity video lamp \\
\hline Electronic load & Chroma 6310 \\
\hline Controller & dSPACE DS1103 controller board \\
\hline Power Converter & $\begin{array}{l}\text { Step-up, efficiency } 90 \% \\
L=90 \mathrm{uH}, \mathrm{C}=470 \mathrm{uF}, f_{\mathrm{s}}=50 \mathrm{kHz}\end{array}$ \\
\hline
\end{tabular}

by using Matlab/Simulink and then compiled and executed on a general purpose real-time controller that managed switching duty of the power converter. The main parameters of the system are listed in Table III. In the power converter circuit, capacitor $C_{1}(470 \mu \mathrm{F})$ filters the switching ripple at $f s=50 \mathrm{kHz}$, which is a much higher frequency than that associated with the solar power fluctuations of interest. Within the control bandwidth, the capacitor voltage is always in equilibrium with the voltage of the PV array which is itself constant since our control objective is to maintain a constant converter input voltage (also equal to the solar array voltage and $C_{1}$ voltage). The capacitor voltage ripple $\Delta v_{C 1}$ caused by switching is small enough to ignore (about $10 \mathrm{mV}$ in this paper) and can be estimated as $\Delta v_{C 1}=\Delta i_{L} /\left(8 \cdot C_{1} \cdot f s\right)$ [31], where $\Delta i_{L}$ is the inductor current ripple in one switch cycle.

Fig. 6 shows the measured power generated as a function of voltage using stationary shadings. Three different shadings, which had similar shape patterns, as shown in Fig. 4(d), were applied with shading area $42 \%, 53 \%$, and $63 \%$ corresponding to Shade 1, 2, and 3 in Fig. 6. It is noted that the voltage corresponding to the MPP is $0.62 \mathrm{~V}$, and this voltage was then specified as the MPP reference for the PV array at room temperature. Figs. 7 and 8 show the dynamic performance of the PV system during a 130-s experiment. The illumination conditions during the test changed continually and quickly $(\sim 1 / 10$ s) by randomly shading the PV panel surface to simulate movements in a portable application. Fig. 7 shows that the output current of the PV panel changed significantly according to the irradiance variations, but the terminal voltage of the PV panel was controlled to be nearly constant at $0.62 \mathrm{~V}$.

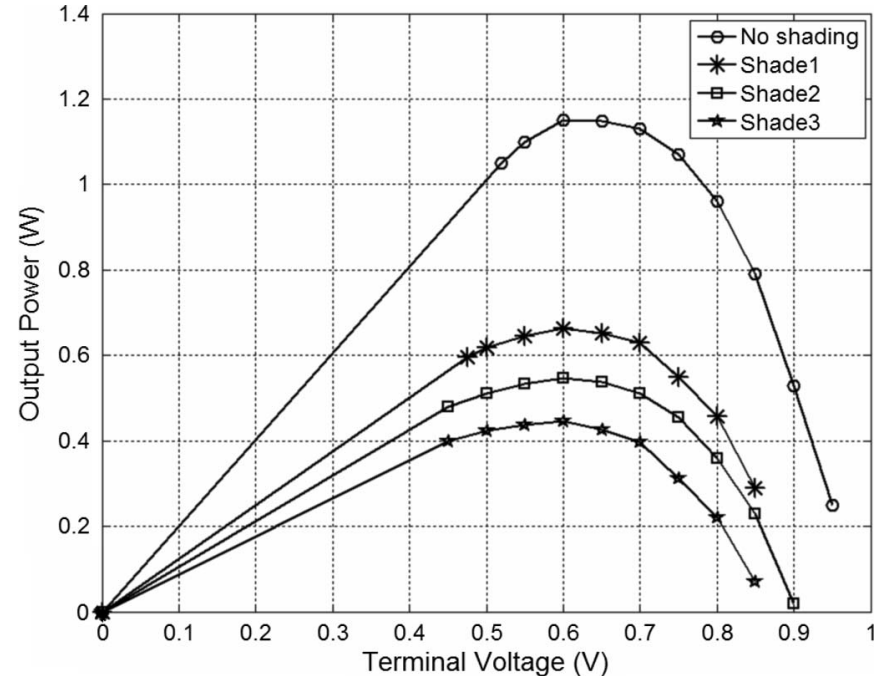

Fig. 6. Experimental $P-V$ characteristics.

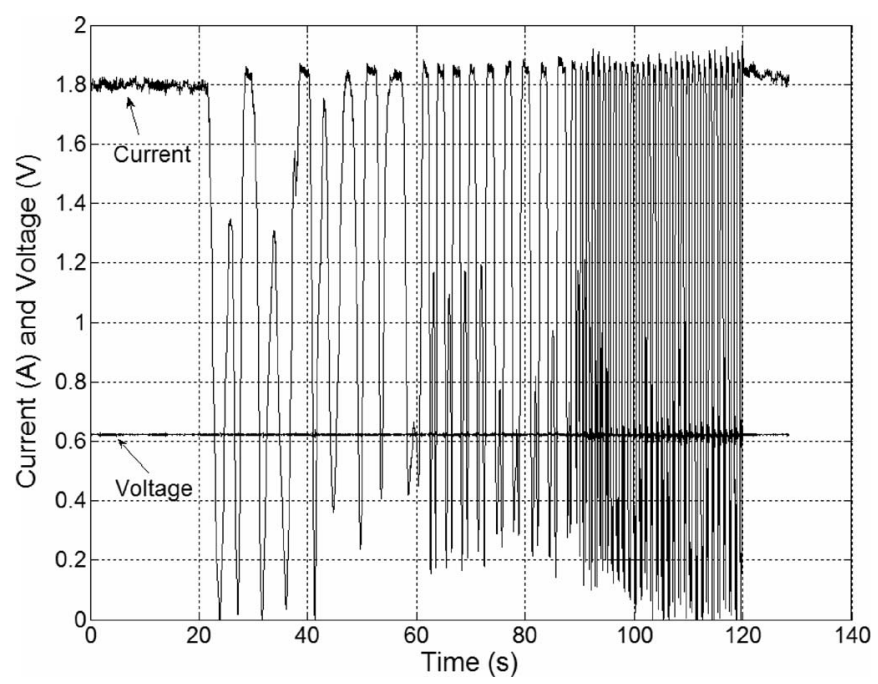

Fig. 7. Voltage and current during 130-s experimental test.

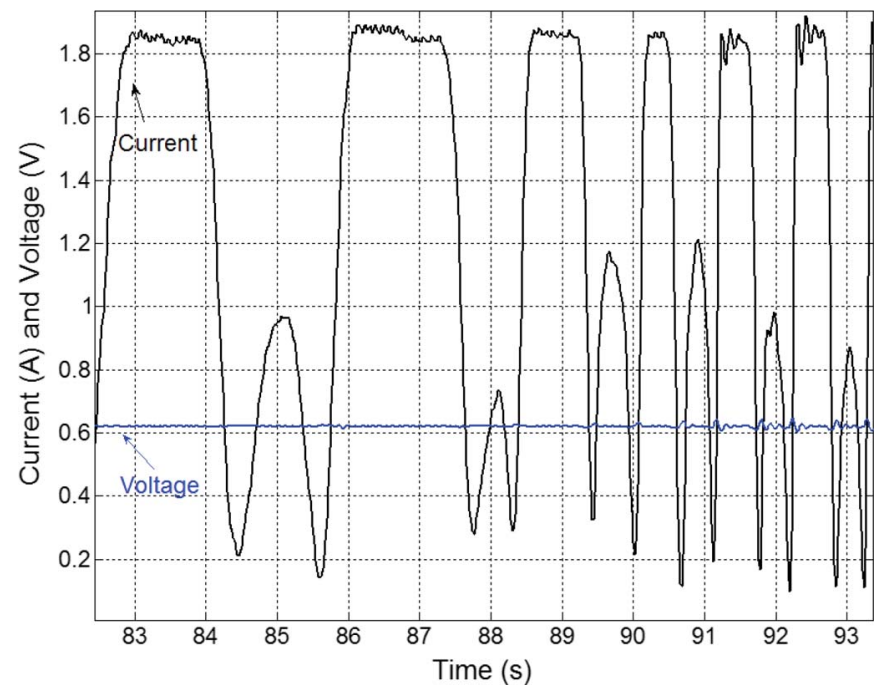

Fig. 8. Zoom-in view of experimental test from 83 to $93 \mathrm{~s}$.

Fig. 8 shows a zoom-in view of the experimental test from 83 to $93 \mathrm{~s}$. It can be seen that the MPP tracker did follow the rapidly changing illumination well. Therefore, by controlling 


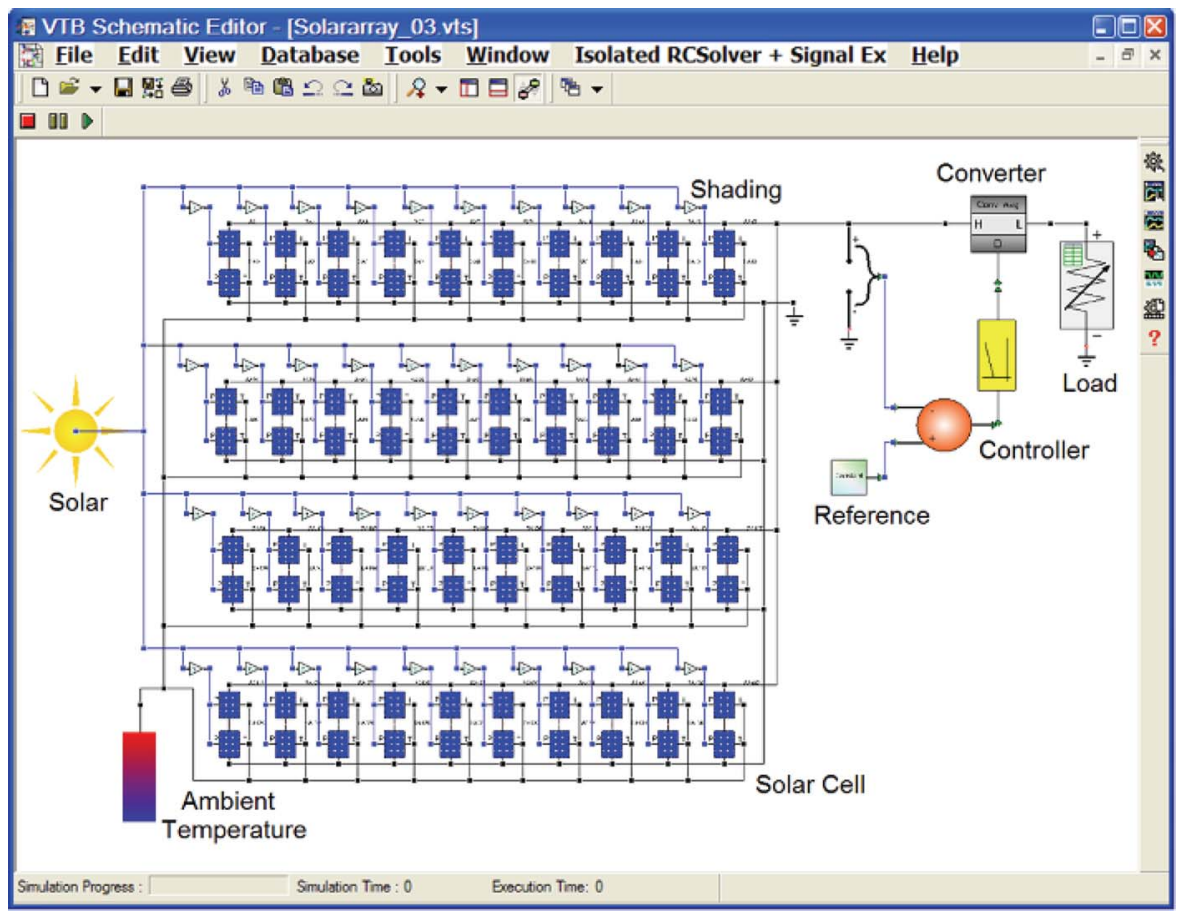

Fig. 9. Simulation schematic for parallel-connected PV system.

the PV panel operating voltage, the MPPT was implemented, and maximum power was generated under rapid time-varying irradiance conditions.

\section{Discussions}

\section{A. Compare Ideal Energy Harvest to the Parallel PV System}

The ideal maximum energy harvest for a PV panel is that every cell in the panel operates at its MPP, and all the generated energy is collected. Although it is really hard to monitor it in experiments under complex illuminations, the ideal maximum energy harvest can be calculated from the PV cell model assuming every cell in the panel loaded at its won MPP voltage corresponding to the different irradiance levels.

A simulation study was carried out to compare the ideal energy harvest to the proposed PV system under complex illuminations. The PV cell model described in [32] and the Virtual Test Bed simulation tool [33] were applied in this paper. Fig. 9 shows the simulation schematic of parallel-connected PV system. The simulation system was set according to the experimental system in Table III and Fig. 1. Fig. 10 shows a zoom-in view. Each PV string (with two cells in series) was randomly and partially blocked by a shading model. As a result, the received irradiance level was fluctuated in the range from 100 to $1000 \mathrm{~W} / \mathrm{m}^{2}$.

Fig. 11 shows the irradiance fluctuations falling on two arbitrarily chosen PV strings during a 3600-s simulation. Fig. 12 shows the PV panel terminal voltage that was controlled to be constant at $0.62 \mathrm{~V}$. Fig. 13 shows the power generation during the simulation.

The energy generation of the proposed PV system during the simulation was then obtained by integrating the power curve in Fig. 13. Comparing it to the ideal maximum energy harvest, the

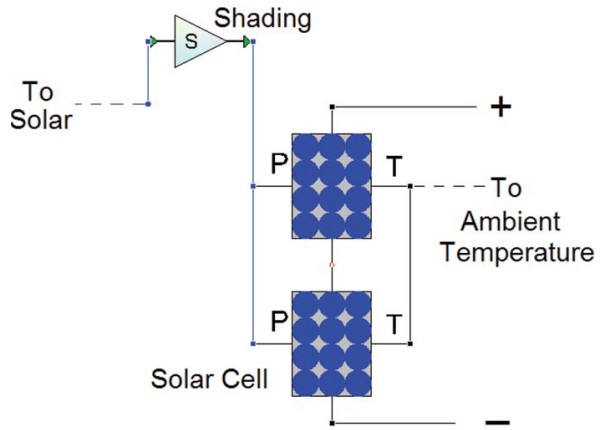

Fig. 10. Zoom-in view of a PV pair in Fig. 9.

performance of the proposed system achieves around $96 \%$ of the ideal maximum value. The $4 \%$ of energy loss was mainly due to the fact that the MPP voltages at different irradiance levels are slightly different, which is analyzed as follows by comparing the energy produced by all the PV cells with each loaded at their own ideal voltage to all the cells loaded at one common voltage.

Fig. 14 shows the output power of a PV cell at $300 \mathrm{~K}$ as a function of terminal voltage and parameterized by irradiance level from 100 to $1000 \mathrm{~W} / \mathrm{m}^{2}$ at increments of $100 \mathrm{~W} / \mathrm{m}^{2}$. As shown in Fig. 14, the two nearly vertical lines marked with circles bound the region in which the PV cells provide at least $95 \%$ of the maximum power at each irradiance level. Between the two 95\% power lines, the curves are rather flat, and the peak power is only weakly sensitive to voltage; therefore, loading a partially shaded cell at the same voltage as a fully illuminated cell only slightly reduces the power supplied.

For the case of ten cells each illuminated at the ten levels shown in Fig. 14, the power reduction is estimated and shown in Table IV. It can be seen that with $\pm 5 \%$ deviation from the 


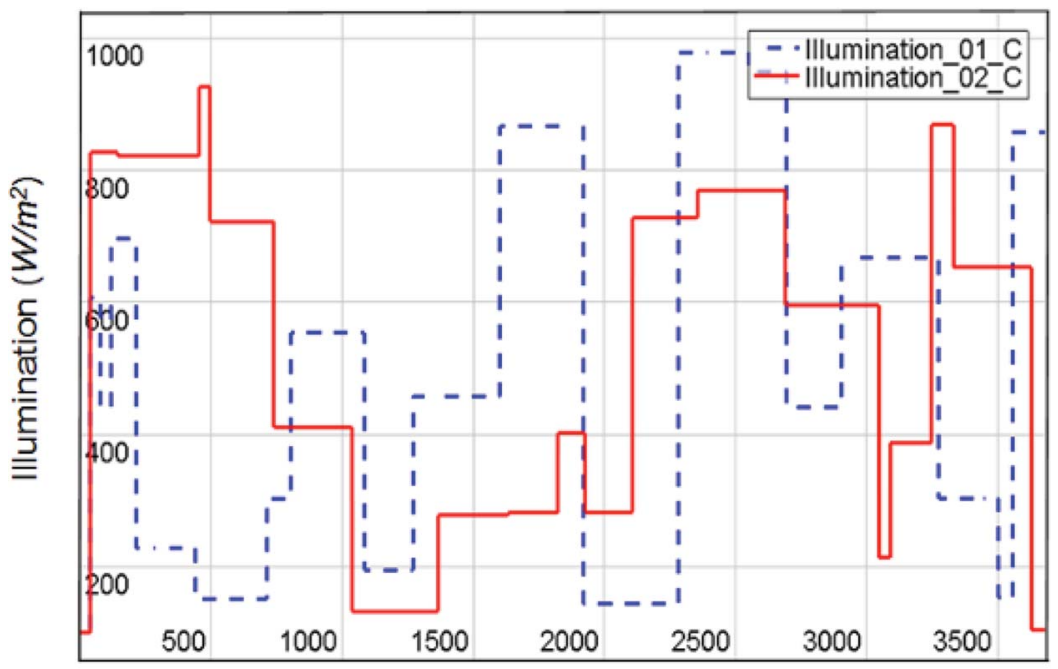

Time (s)

Fig. 11. Irradiance level versus simulation time.

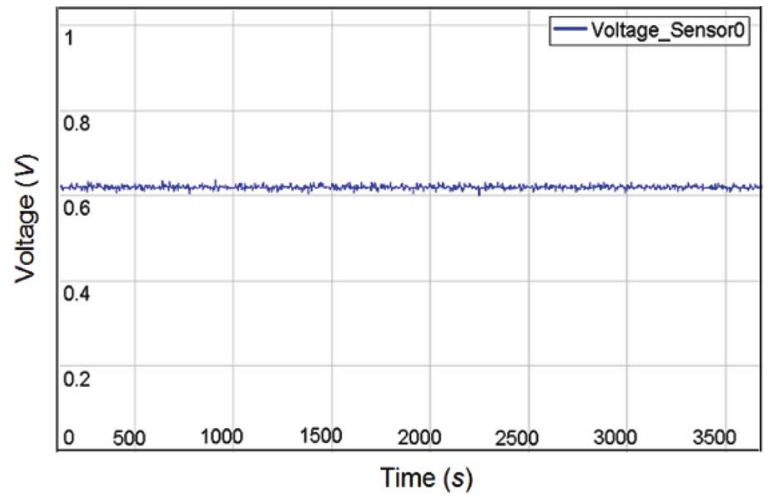

Fig. 12. PV panel terminal voltage.

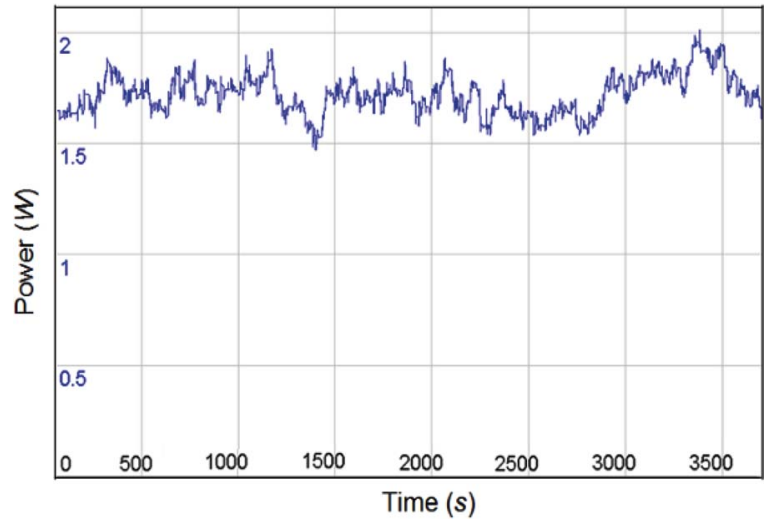

Fig. 13. Power generation from the PV panel.

voltage corresponding to the MPP $V_{P M a x}$ of the PV array, the power reduction is less than $3.5 \%$ of the ideal maximum power generation.

\section{B. Compare Serial and Parallel Arrays With MPPT Algorithm}

In Section III, the parallel configuration without MPPT has demonstrated better performance than the series configuration without MPPT under various shading conditions. Here,

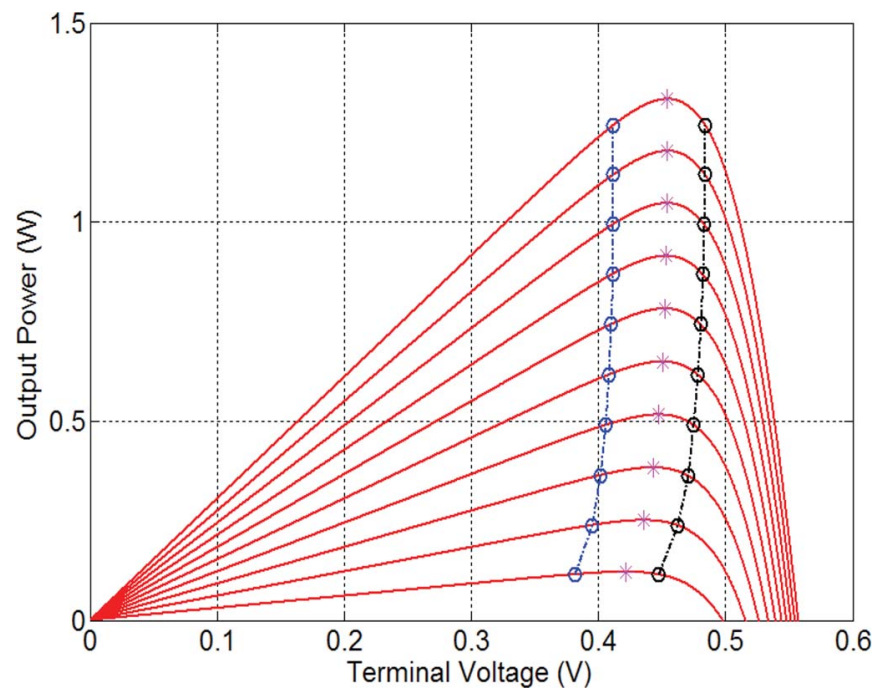

Fig. 14. Output power versus terminal voltage.

TABLE IV

POWER GENERATION COMPARISON

\begin{tabular}{c|c|c|c}
\hline$i$ & $\begin{array}{c}\text { PV array operation } \\
\text { voltage with ten cells- } \\
\text { in-parallel }\end{array}$ & $\begin{array}{c}\text { Power } \\
\text { generated at } \\
\text { operation } \\
\text { voltage }\end{array}$ & $P(i) \div P_{\text {IdealMaxPower }}$ \\
\hline 1 & $V_{P M a x}$ & $P(1)$ & $99.79 \%$ \\
\hline 2 & $V_{P M a x} \cdot(100 \%-1 \%)$ & $P(2)$ & $99.71 \%$ \\
\hline 3 & $V_{P M a x} \cdot(100 \%-5 \%)$ & $P(3)$ & $98.02 \%$ \\
\hline 4 & $V_{P M a x} \cdot(100 \%+1 \%)$ & $P(4)$ & $99.70 \%$ \\
\hline 5 & $V_{P M a x} \cdot(100 \%+5 \%)$ & $P(5)$ & $96.85 \%$ \\
\hline
\end{tabular}

simulation studies were taken to compare them with MPPT, and all simulation parameters were specified according to the experiments in Table I. The MPPT method of constant voltage control was applied for both of the systems in order to yield comparable results. Specifically, 0.93 and $6.2 \mathrm{~V}$ were set as the voltage references for the parallel configuration and the series configuration. 


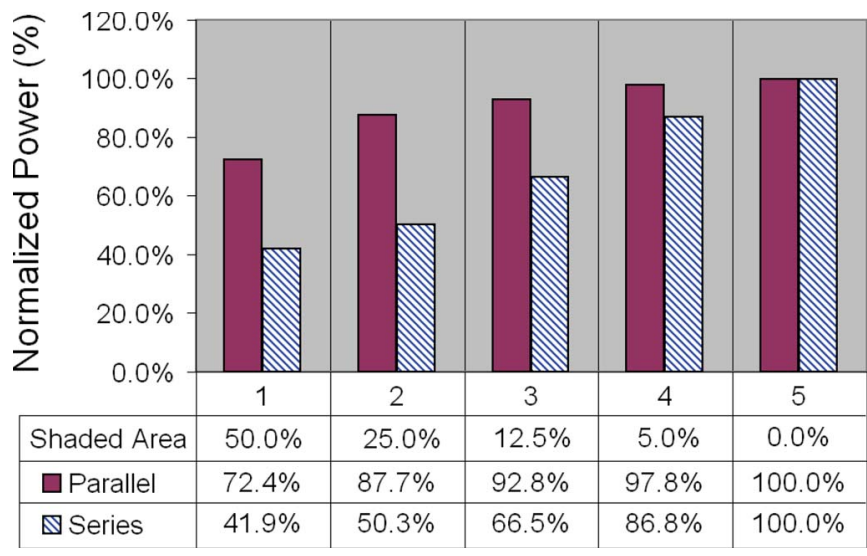

Fig. 15. Performance comparisons using translucent shading spots.

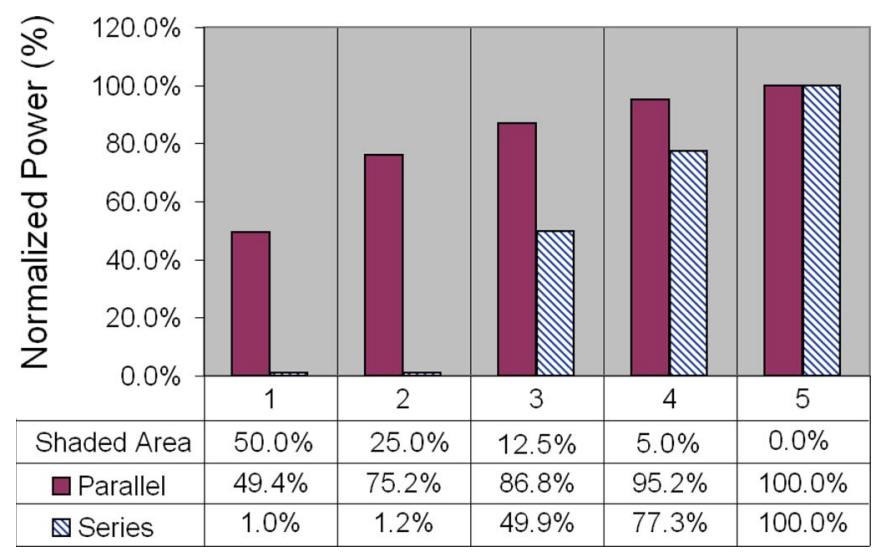

Fig. 16. Performance comparisons using opaque shading spots.

Two sets of simulations were taken during which rapid changing shading conditions were applied and different fractions of the PV panel were shaded. Specifically, in the first set of simulations, translucent spots with different sizes dynamically shaded the PV panel. As a consequence, the irradiance level falling on the blocked PV cells was as a half as that on the unblocked cells. While in the second set of simulations, opaque spots were applied thus the blocked cells were fully shaded. During each simulation, different cells were shaded at different time instants, but the total area of blocked cells was constant. Figs. 15 and 16 show comparisons between the two systems and the parallel configurations yielded better performance.

\section{CONCLUSION}

This paper has described the configuration of a portable PV power system that produced maximum power under rapidly changing partial shading conditions such as would be encountered in portable applications. Under complex irradiance conditions, the power generating capability of the proposed PV system was approximately twice that of a conventionally configured series system. The developed approach is broadly applicable, but is perhaps most valuable in PV systems having high single-cell voltages where direct input to a high-efficiency converter is most practical.

\section{REFERENCES}

[1] B. E. A. Saleh and M. C. Teich, Fundamentals of Photonics. New York: Wiley, 1991.

[2] R. Dougal, L. Gao, S. Liu, and A. Iotova, "Apparatus and method for enhanced solar power generation and maximum power point tracking," Patent PCT Number WO 2007/124059 A2, Nov. 2007.

[3] L. Gao, R. A. Dougal, S. Liu, and A. Iotova, "Portable solar systems using a step-up power converter with a fast-speed MPPT and a parallelconfigured solar panel to address rapidly changing illumination," in Proc. IEEE APEC, Anaheim, CA, Mar. 2007, pp. 520-523.

[4] H. Koizumi and K. Kurokawa, "A novel maximum power point tracking method for PV module integrated converter," in Proc. IEEE Power Electron. Spec. Conf., 2005, pp. 2081-2086.

[5] H. Oldenkamp, I. Jong, N. Borg, B. Boer, H. Moor, and W. Sinke, "PVWirefree versus conventional PV systems: Detailed analysis of difference in energy yield between series and parallel connected PV modules," in Proc. 19th Eur. Photovoltaic Solar Energy Conf., Paris, France, Jun. 2004.

[6] W. Xiao, N. Ozog, and W. G. Dunford, "Topology study of photovoltaic interface for maximum power point tracking," IEEE Trans. Ind. Electron., vol. 54, no. 3, pp. 1696-1704, Jun. 2007.

[7] R. Gules, J. De Pellegrin Pacheco, H. L. Hey, and J. Imhoff, "A maximum power point tracking system with parallel connection for PV stand-alone applications," IEEE Trans. Ind. Electron., vol. 55, no. 7, pp. 2674-2683, Jul. 2008.

[8] O. Wasynczuck, "Dynamic behavior of a class of photovoltaic power systems," IEEE Trans. App. Syst., vol. PAS-102, no. 9, pp. 3031-3037, Sep. 1983.

[9] M. Calais and H. Hinz, "A ripple-based maximum power point tracking algorithm for a single-phase, grid-connected photovoltaic system," Sol. Energy, vol. 63, no. 5, pp. 277-282, Nov. 1998.

[10] N. Femia, G. Petrone, G. Spagnuolon, and M. Vitelli, "Optimization of Perturb and observe maximum power point tracking method," IEEE Trans. Power Electron., vol. 20, no. 4, pp. 963-973, Jul. 2005.

[11] N. Kasa, T. Iida, and L. Chen, "Flyback inverter controlled by sensorless current MPPT for photovoltaic power system," IEEE Trans. Ind. Electron., vol. 52, no. 4, pp. 1145-1152, Aug. 2005.

[12] W. Xiao, W. G. Dunford, P. R. Palmer, and A. Capel, "Application of centered differentiation and steepest descent to maximum power point tracking," IEEE Trans. Ind. Electron., vol. 54, no. 5, pp. 2539-2549, Oct. 2007.

[13] Y. C. Kuo, T. J. Liang, and J. F. Chen, "Novel maximum-power-pointtracking controller for photovoltaic energy conversion system," IEEE Trans. Ind. Electron., vol. 48, no. 3, pp. 594-601, Jun. 2001.

[14] K. Hussein, I. Muta, T. Hoshino, and M. Osakada, "Maximum photovoltaic power tracking: An algorithm for rapidly changing atmospheric conditions," Proc. Inst. Elect. Eng.-Gener. Transm. Distrib., vol. 142, no. 1, pp. 59-64, Jan. 1995.

[15] M. Veerachary, T. Senjyu, and K. Uezato, "Neural-network-based maximum-power-point tracking of coupled-inductor interleaved-boostconverter-supplied PV system using fuzzy controller," IEEE Trans. Ind. Electron., vol. 50, no. 4, pp. 749-758, Aug. 2003.

[16] T. Hiyama, S. Kouzuma, and T. Imakubo, "Identification of optimal operating point of $\mathrm{PV}$ modules using neural network for real time maximum power tracking control," IEEE Trans. Energy Convers., vol. 10, no. 2, pp. 360-367, Jun. 1995.

[17] K. Ro and S. Rahman, "Two-loop controller for maximizing performance of a grid-connected photovoltaic-fuel cell hybrid power plant," IEEE Trans. Energy Convers., vol. 13, no. 3, pp. 276-281, Sep. 1998.

[18] N. Patcharaprakiti and S. Premrudeepreechacharn, "Maximum power point tracking using adaptive fuzzy logic control for grid-connected photovoltaic system," in Proc. IEEE Power Eng. Soc. Winter Meeting, 2002, pp. 372-377.

[19] N. Mutoh, M. Ohno, and T. Inoue, "A method for MPPT control while searching for parameters corresponding to weather conditions for PV generation systems," IEEE Trans. Ind. Electron., vol. 53, no. 4, pp. 10551065, Jun. 2006.

[20] N. Femia, D. Granozio, G. Petrone, G. Spagnuolo, and M. Vitelli, "Optimized one-cycle control in photovoltaic grid connected applications," IEEE Trans. Aerosp. Electron. Syst., vol. 42, no. 3, pp. 954-972, Jul. 2006.

[21] K. Chomsuwan, P. Prisuwanna, and V. Monyakul, "Photovoltaic gridconnected inverter using two-switch buck-boost converter," in Proc. 29th IEEE Photovoltaic Spec. Conf., 2002, pp. 1527-1530.

[22] L. Asiminoaei, R. Teodorescu, F. Blaabjerg, and U. Borup, "A digital controlled PV-inverter with grid impedance estimation for ENS detection," IEEE Trans. Power Electron., vol. 20, no. 6, pp. 1480-1490, Nov. 2005. 
[23] H. Patel and V. Agarwal, "Maximum power point tracking scheme for PV systems operating under partially shaded conditions," IEEE Trans. Ind. Electron., vol. 55, no. 4, pp. 1689-1698, Apr. 2008.

[24] J. J. Schoeman and J. D. van Wyk, "A simplified maximal power controller for terrestrial photovoltaic panel arrays," in Proc. 13th Annu. Power Electron. Spec. Conf., Cambridge, MA, Jun. 14-17, 1982, pp. 361-367.

[25] G. W. Hart, H. M. Branz, and C. H. Cox, "Experimental tests of open-loop maximum-power-point tracking techniques for photovoltaic arrays," Sol. Cells, vol. 13, pp. 185-195, Dec. 1984.

[26] J. H. R. Enslin, M. S. Wolf, D. B. Snyman, and W. Swiegers, "Integrated photovoltaic maximum power point tracking converter," IEEE Trans. Ind. Electron., vol. 44, no. 6, pp. 769-773, Dec. 1997.

[27] R. Wai and W. Wang, "Grid-connected photovoltaic generation system," IEEE Trans. Circuits Syst. I, Reg. Papers, vol. 55, no. 3, pp. 953-964, Apr. 2008.

[28] N. Femia, G. Lisi, G. Petrone, G. Spagnuolo, and M. Vitelli, "Distributed maximum power point tracking of photovoltaic arrays: Novel approach and system analysis," IEEE Trans. Ind. Electron., vol. 55, no. 7, pp. 26102621, Jul. 2008.

[29] G. R. Walker and P. C. Sernia, "Cascaded DC-DC converter connection of photovoltaic modules," IEEE Trans. Power Electron., vol. 19, no. 4, pp. 1130-1139, Jul. 2004.

[30] L. M. Tolbert and F. Z. Peng, "Multilevel converters as a utility interface for renewable energy systems," in Proc. IEEE PES Summer Meeting, Seattle, WA, Jul. 16-20, 2000, vol. 2, pp. 1271-1274.

[31] R. W. Erickson and D. Maksimovic, Fundamentals of Power Electronics. New York: Chapman \& Hall, 1997.

[32] S. Liu and R. A. Dougal, "Dynamic multiphysics model for solar array," IEEE Trans. Energy Convers., vol. 17, no. 2, pp. 285-294, Jun. 2002.

[33] The Virtual Test Bed, Univ. South Carolina, Columbia, SC. [Online]. Available: http://www.vtb.engr.sc.edu/

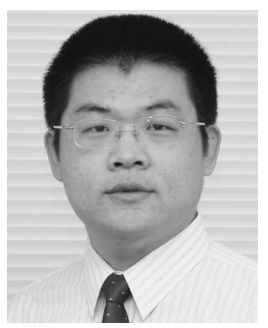

Lijun Gao (M'04-SM'08) received the Ph.D degree in electrical engineering from the University of South Carolina, Columbia, in 2003.

$\mathrm{He}$ is currently an Electrical Design and Analysis Engineer with the Boeing Company, Seattle, WA His interests include modeling and control of advanced electrical power systems, design, and application of power electronics.

Dr. Gao is a member of the Society of Automotive Engineers.

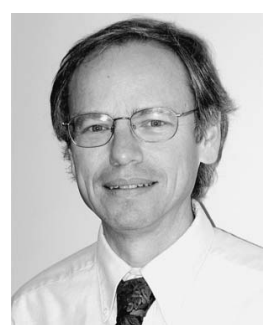

Roger A. Dougal (S'74-M'78-SM'94) received the $\mathrm{Ph} . \mathrm{D}$. degree from Texas Tech University, Lubbock, in 1983.

He is currently the Thomas Gregory Professor of Electrical Engineering at the University of South Carolina, Columbia. He directs the Virtual Test Bed project that aims to advance the technologies for simulation-based design and virtual prototyping of dynamic multidisciplinary systems. Active research thrusts include methods for dynamically variable model resolution, partitioning and multirate solutions of large systems, and the applicability of online multiplayer gaming principles to design of large and complex systems. His work also addresses issues in abstract representation and optimization of systems in an interdisciplinary and multiobjective sense. He is the Director of the Electric Ship R\&D Consortium which is developing electric power technologies for the next generation of electric warships, and his grounding is in the fields of power electronics, physical electronics, and electrochemical power sources.

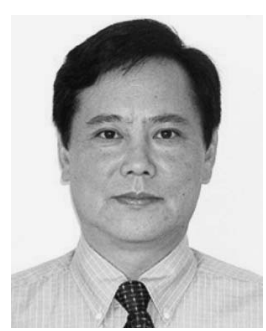

Shengyi Liu (SM'03) received the Ph.D. degree in electrical engineering from the University of South Carolina, Columbia, in 1995.

From 1995 to 1999 , he was a Senior Research and Development Engineer with InnerLogic Inc., Charleston, SC. From 1999 to 2006, he was a Research Professor with the Department of Electrical Engineering, University of South Carolina. Since November 2006, he has been the Manager of Platform Subsystems Technology, The Boeing Phantom Works, Seattle, WA. He also serves as a Program Manager for the contract project of the Defense Advanced Research Projects Agency Unmanned Underwater Vehicle Power System project. He is specialized in high power and high energy density power and energy system design and integration for space, ground, surface, and subsurface vehicle applications.

Dr. Liu is a member of the American Institute of Aeronautics and Astronautics and the Society of Automotive Engineers. He is a Licensed Professional Engineer in the State of Washington.

Albena P. Iotova, photograph and biography not available at the time of publication. 